\title{
Two Promising Novel Classes of Drug Treatment in Clinical Development for Acute and Chronic Spinal Cord Injury
}

Pierre Guertin ${ }^{1,2 *}$

${ }^{1}$ Department of Psychiatry and Neurosciences, Laval University, Quebec City, Quebec, Canada

${ }^{2}$ Nordic Life Science Pipeline Inc, Quebec City, Quebec, Canada

\section{Editorial}

Spinal Cord Injury (SCI) can occur accidentally (i.e., trauma caused by motor vehicle accident, fall, gun shot, etc.) or be caused by a disease (i.e., non-traumatic SCI associated with diseases such as multiple sclerosis, spinal tumor, vascular problems, etc.) [1].

In traumatic SCI, the initial injury results into spinal cord deformation, laceration, crush and persistent post-injury cord compression occurring within seconds to minutes post-accident. This leads to immediate cell death, axonal disruption, vascular and metabolic changes, which have subsequent effects or so-called secondary injury processes occurring within a few minutes to a few weeks of injury [2-4].

Subsequently, within a few weeks to a few months post-trauma (chronic SCI), the patient generally experiences the development of several serious medical problems. They typically develop cardiovascular problems, type II diabetes, sarcopenia, osteoporosis, immune deficiencies and other life-threatening problems [5-13]. The cellular mechanisms underlying these so-called secondary complications or comorbid problems remain unclear and no drug treatment has been developed to specifically treat these medical concerns. However, a plethora of symptomatic treatments are often prescribed to separately control some of these complications expressed in both traumatic and non-traumatic SCI patients [14].

I strongly believe that the lack of treatment in clinical development either for acute or chronic problems may be attributed to at least two factors. First, most technologies (cell-based, neurotrophic factors, etc.) identified in rodents were found, for several reasons, to lack reproducibility [15]. It is generally accepted that damage to neuronal function following SCI arises from a complex series of reactions. A key determinant of functional loss after SCI is the extent of damage to projection axons at the lesion site, and axons do not regenerate spontaneously even though their cell bodies may remain alive. Failure of self-repair is caused by growth inhibitory proteins [2-4], which are especially prevalent in regions of white matter and long axonal tracts. They act by affecting signaling pathways that regulate the growth cone cytoskeleton. As mentioned above, although a few technologies were found in animal models to reduce the inhibitory actions of growth inhibitory proteins, none has been approved. This said, a Rho inhibitor called Cethrin ${ }^{\mathrm{TM}}$ is probably the most advanced technology as of now. It is one of the rare treatment candidates that has successfully completed preclinical studies and first-in-patient safety study (Phase I/IIa) [16]. It is currently in preparation for a Phase IIb study in acute SCI patients.

Secondly, no animal model ideally suited to investigate the development of comorbid problems in chronic SCI had been developed until recently [17-21]. In fact, we have been the first group to have recently developed a model of chronic SCI in which systemic and metabolic problems were thoroughly characterized [22]. In parallel to these experiments, we also identified and developed a drug product aimed to prevent several of these chronic problems after SCI by activating pharmacologically a spinal locomotor network based in the lumbar area of the spinal cord [23-25]. This is the first and still the only drug treatment candidate in development for chronic SCIrelated health problems. The technology that is called Spinalon ${ }^{\mathrm{TM}}$ has undertaken in 2012 its first clinical trials in chronic SCI patients (http:// clinicaltrials.gov/ct2/show/NCT01484184?term= spinalon\&rank=1).

Now, let's only hope, after so many years of research in SCI, that these two promising technologies designed specifically for acute and chronic SCI patients respectively will succeed in moving along the difficult and risky path of clinical development. If eventually approved by regulatory authorities, they may constitute in approximately five (5) years two novel classes of safe and potent drug treatments for SCI patients.

Nearly 1.3 million people are currently living with a traumatic SCI in North America (www. Christopherreeve.org) making of SCI the first neurological problem only second to Alzheimer's disease (4.5 million cases, www.cdc.com).

\section{References}

1. Rouleau P, Ayoub E, Guertin PA (2011) Traumatic and non-traumatic spinal cord-injured patients in Quebec, Canada: Part 1 - Epidemiological, clinical and functional characteristics. Open Epidemiol J 4: 133-139.

2. McKerracher L, David S (2004) Easing the brakes on spinal cord repair. Nat Med 10: 1052-1053.

3. Schwab ME (2002) Increasing plasticity and functional recovery of the lesioned spinal cord. Prog Brain Res 137: 351-359.

4. Ruff RL, McKerracher L, Selzer ME (2008) Repair and neurorehabilitation strategies for spinal cord injury. Ann N Y Acad Sci 1142: 1-20.

5. Apstein MD, George BC (1998) Serum lipids during the first year following acute spinal cord injury. Metabolism 47: 367-370.

6. Burnham R, Martin T, Stein R, Bell G, MacLean I, et al. (1997) Skeletal muscle fibre type transformation following spinal cord injury. Spinal Cord 35: 86-91.

7. Gerrits HL, De Haan A, Hopman MT, van Der Woude LH, Jones DA, et al. (1999) Contractile properties of the quadriceps muscle in individuals with spinal cord injury. Muscle Nerve 22: 1249-1256.

*Corresponding author: Pierre A. Guertin, Department of Psychiatry and Neurosciences, Laval University, 2705 Laurier Boulevard, RC-9800, Quebec City, G1V 4G2, Canada, E-mail: Pierre.Guertin@crchul.ulaval.ca

Received May 09, 2012; Accepted May 09, 2012; Published May 12, 2012

Citation: Guertin P (2012) Two Promising Novel Classes of Drug Treatment in Clinical Development for Acute and Chronic Spinal Cord Injury. J Neurol Neurophysiol 3:e107. doi:10.4172/2155-9562.1000e107

Copyright: ( 2012 Guertin P. This is an open-access article distributed under the terms of the Creative Commons Attribution License, which permits unrestricted use, distribution, and reproduction in any medium, provided the original author and source are credited. 
Citation: Guertin P (2012) Two Promising Novel Classes of Drug Treatment in Clinical Development for Acute and Chronic Spinal Cord Injury. J Neurol Neurophysiol 3:e107. doi:10.4172/2155-9562.1000e107

8. Grimby G, Broberg C, Krotkiewska I, Krotkiewski M (1976) Muscle fiber composition in patients with traumatic cord lesion. Scand J Rehabil Med 8: $37-42$.

9. Mechanick JI, Pomerantz F, Flanagan S, Stein A, Gordon WA, et al. (1997) Parathyroid hormone suppression in spinal cord injury patients is associated with the degree of neurologic impairment and not the level of injury. Arch Phys Med Rehabil 78: 692-696.

10. Naftchi NE, Viau AT, Sell GH, Lowman EW (1980) Pituitary-testicular axis dysfunction in spinal cord injury. Arch Phys Med Rehabil 61: 402-405.

11. Scott WB, Lee SC, Johnston TE, Binkley J, Binder-Macleod SA (2006) Contractile properties and the force-frequency relationship of the paralyzed human quadriceps femoris muscle. Phys Ther 86: 788-799.

12. Bauman WA, Spungen AM, Adkins RH, Kemp BJ (1999) Metabolic and endocrine changes in persons aging with spinal cord injury. Assist Technol 11: $88-96$.

13. Zehnder Y, Lüthi M, Michel D, Knecht H, Perrelet R, et al. (2004) Long-term changes in bone metabolism, bone mineral density, quantitative ultrasound parameters, and fracture incidence after spinal cord injury: A cross-sectional observational study in 100 paraplegic men. Osteoporos Int 15: 180-189.

14. Rouleau P, Guertin PA (2011) Traumatic and nontraumatic spinal-cord-injured patients in Quebec, Canada. Part 3: pharmacological characteristics. Spinal Cord 49: 186-195.

15. Steward O, Popovich PG, Dietrich WD, Kleitman N (2012) Replication and reproducibility in spinal cord injury research. Exp Neurol 233: 597-605.

16. Fehlings MG, Theodore N, Harrop J, Maurais G, Kuntz C, et al. (2011) A phase I/lla clinical trial of a recombinant Rho protein antagonist in acute spinal cord injury. J Neurotrauma 28: 787-796.
17. Basso DM, Beattie MS, Bresnahan JC (1996) Graded histological and locomotor outcomes after spinal cord contusion using the NYU weight-drop device versus transection. Exp Neurol 139: 244-256.

18. Farooque M (2000) Spinal cord compression injury in the mouse: presentation of a model including assessment of motor dysfunction. Acta Neuropathol 100: 13-22.

19. Kwon BK, Oxland TR, Tetzlaff W (2002) Animal models used in spinal cord regeneration research. Spine (Phila Pa 1976) 27: 1504-1510.

20. Sheng H, Wang H, Homi HM, Spasojevic I, Batinic-Haberle I, et al. (2004) A no-laminectomy spinal cord compression injury model in mice. J Neurotrauma 21: $595-603$

21. Steward O, Schauwecker PE, Guth L, Zhang Z, Fujiki M, et al. (1999) Genetic approaches to neurotrauma research: opportunities and potential pitfalls of murine models. Exp Neurol 157: 19-42.

22. Ung RV, Lapointe NP, Guertin PA (2008) Early adaptive changes in chronic paraplegic mice: a model to study rapid health degradation after spinal cord injury. Spinal Cord 46: 176-180.

23. Ung RV, Rouleau P, Guertin PA (2011) Functional and Physiological Effects of Treadmill Training Induced by Buspirone, Carbidopa, and L-DOPA in Clenbuterol-Treated Paraplegic Mice. Neurorehabil Neural Repair.

24. Guertin PA, Ung RV, Rouleau P, Steuer I (2011) Effects on locomotion, muscle bone, and blood induced by a combination therapy eliciting weight-bearing stepping in nonassisted spinal cord-transected mice. Neurorehabil Neural Repair 25: 234-242.

25. Guertin PA, Ung RV, Rouleau P (2010) Oral administration of a tri-therapy for central pattern generator activation in paraplegic mice: proof-of-concept of efficacy. Biotechnol J 5: 421-426. 